\title{
KOMERCINĖS İMONÉS ERGONOMINIŲ RIZIKOS VEIKSNIŲ VALDYMAS
}

\author{
Algirdas GiedRAITIS ${ }^{1}$
}

Klaipėdos universitetas (Lietuva)

\begin{abstract}
ANOTACIJA
Straipsnyje nagrinejami ergonominių rizikos veiksnių valdymo klausimai komercinės įmonės darbo aplinkoje. Daugelis darbdavių vis dar nevertina to, kad investuojant $i ̣$ ịvairių ergonominių rizikos veiksnių valdymą ir prevencinių priemonių šių veiksnių rizikai šalinti taikymą gali būti teikiama nauda tiek įmonei, tiek jos darbuotojams. Teoriškai nustatyta, kad organizacijoje siekiant maksimalaus rezultato, būtina valdyti ergonominius rizikos veiksnius ir tinkamai parinkti organizacijos tikslus bei jų igyvendinimo būdus. Praktinis tyrimas, atliktas komercinėje įmonèje, parodè, kad apklaustiems tyrimo dalyviams ergonominiai reikalavimai darbo aplinkoje yra svarbūs, manytina, kad ergonominių rizikos veiksnių valdymas tampa įmonès veiklos dalimi ir padeda tobulinti ne tik įmonès, bet ir šios rinkos ergonominių rizikos veiksnių valdymo procesą. Todèl siekiant didinti darbuotojų indèli ị ịmonės veiklą, ergonominių rizikos veiksnių poveikio įmonėse valdymas tampa veiksmingu nelaimingų atsitikimų darbe ir susirgimų profesinėmis ligomis mažinimo būdu, kartu šalinami organizacinio pobūdžio pažeidimai.
\end{abstract}

PAGRINDINIAI ŽODŽIAI: ergonominiai rizikos veiksniai, valdymo procesas, prevencinès priemonès, darbo aplinka.

JEL KLASIFIKACIJA: M12, R11

Ivadas

Siekiant didinti ūkio našumą Vakarų Lietuvos regione, skatinti inovacijų taikymą ir tvarų ekonomikos augimą, daugiau dèmesio reikia skirti darbuotojų darbo aplinkai. Būtini bendri veiksmai, kurie skatintų konkurencingumą ir padètų toliau vystyti Vakarų Lietuvos regioną išnaudojant jo galimybes. Veiksmų programoje pagal visas prioritetines kryptis būtina investuoti ị žmogiškujjų išteklių saugą, sudarant palankias sąlygas tobulinti profesinius gebẻjimus ir skatinti naujų žinių bei ịgūdžių igijimą. O diegiant naujas technologijas sudaryti geresnes darbo sąlygas.

Keičiantis socialinėms ir ekonominèms sąlygoms, vykstant ịvairiems pokyčiams, savo veiklos tikslus privalo formuoti kiekvienas organizacijos narys. Darbuotojų rotacija ir kvalifikuotų darbuotojų stoka iškelia naują aktualiją - gero atlyginimo ne visada pakanka, nes įmonès specialistai pageidauja geresnių ir saugesnių darbo sąlygų. Daugelis įmonių vadovų ypač didelị dėmesį skiria nelaimingų atsitikimų prevencijai, bet nepakankamai - su darbu susijusioms ligoms, kurios nulemtos ergonominių rizikos veiksnių poveikio.

Imonejje prognozuojant darbo rezultatus, vertinant ir nagrinejjant esamas netektis dèl ergonominių rizikos veiksnių padarytos žalos, galima gauti daug informacijos, kurios reikia priimant sprendimus dèl investicijų ị prevencines įmonès ergonominių rizikos veiksnių priemones, kadangi saugi darbo aplinka lemia optimalų darbuotojo funkcionavimą, darbingumą, darbo rezultatų kokybę ir pasitenkinimą pačiu darbu. İvairios valdymo sistemos užtikrina, kad būtų valdomi visi veiksniai, turintys įtakos produkto kokybei, toks valdymas

1 Algirdas Giedraitis - Klaipėdos universiteto Socialinių mokslų fakulteto Vadybos katedros lektorius, daktaras (socialiniai mokslai). Moksliniai interesai: valdymo ergonomika, gamybos vadyba, personalo vadyba

El. paštas: giedraitis.algirdas@gmail.com

Tel.: +37046398650 
nukreiptas ị kokybės defektų mažinimą, šalinimą ir, svarbiausia, jų prevenciją. Todėl ergonominių rizikos veiksnių darbo aplinkoje valdymas bet kurio ūkio subjekto veikloje leidžia nustatyti darbo aplinkoje rizikingiausias sritis ir ị jas sutelkus dèmesị priimti atitinkamus sprendimus prognozuojant ateitị bei siekiant konkretaus užsibrèžto tikslo. Išlaidos, susijusios su darbuotojų patiriamomis traumomis, yra didelès, taigi manoma, kad investicijos ị tikslingą pavojingų / kenksmingų ergonominių rizikos veiksnių valdymą gali sumažinti netekimus. Todėl ergonominių rizikos veiksnių valdymas yra svarbiausia profesinės rizikos darbo vietose mažinimo dalis įmonèje siekiant gerų rezultatų.

Ergonominius rizikos veiksnius darbo aplinkoje ir jų valdymą nagrinèjo: K. A. Kaminskas (2007) - ergonominių rizikos veiksnių valdymo Lietuvoje strategijos; K. A. Kaminskas, J. Antanaitis (2010) - ergonomikos rizikos veiksnius mažose ir vidutinèse statybos įmonėse; L. Andruškevičiūtė (2008) - darbo pozas ir krovinių tvarkymą rankomis komercinejje įmonejje; G. Patakauskienè (2008) - ergonominių rizikos veiksnių tyrimo ypatumus komercinèje ịmonèje; G. Kubiliūtè ir K. A. Kaminskas (2011) - ergonominius ir psichosocialinius rizikos veiksnius kelių statybos įmonëje. Prevencines priemones šalinti ergonominius rizikos veiksnius nagrinėjo: A. Seilius ir kt. (2004) - sveikos darbo aplinkos reikalavimus; R. Šukys ir kt. (2011) - profesinių ligų ekonominių ir socialinių pasekmių analizę statybos sektoriuje; R. Rwamamara ir kt. (2010) - traumų prevencines priemones statybos pramoneje; K. A. Kaminskas ir A. Jagniatinskis (2012) - triukšmo poveikio darbo aplinkoje naujas ịvertinimo ir valdymo galimybes. Šie mokslininkai savo tyrimais parodè, kad dauguma Lietuvoje veikiančių įmonių, kurios yra įdiegusios atitinkamas valdymo sistemas, yra pasiekusios nepakankamą standartizuotų (kokybès, aplinkosaugos, darbų saugos) vadybos sistemų brandumo lygi ir nesugeba efektyviai išnaudoti standartų teikiamų galimybių. Todèl dažniausiai šie standartai tampa tik formalaus administravimo atributu arba sèkmès siekimo priedu.

Daugelis darbdavių vis dar nevertina to, kad investuojant ị įvairių ergonominių rizikos veiksnių valdymą ir prevencinių priemonių šių veiksnių rizikai šalinti taikymą gali būti sukuriama nauda tiek ịmonei, tiek jos darbuotojams. Vadovo pasyvumas šiuo klausimu užkerta kelią tiek ergonominių rizikos veiksnių valdymo problemų prevencijai ir ankstyvai diagnostikai, tiek darbuotojų veiksmams, kurie skirti ịmonès problemų stebèsenai ir analizei koordinuoti.

Problema: įmonès vadovų nepakankamas dėmesys ergonominių rizikos veiksnių darbo aplinkoje valdymui siekiant ịmonès tikslų ir mažinant ergonominių rizikos veiksnių neigiamą poveikị dirbantiems darbuotojams.

Tyrimo objektas - ergonominių rizikos veiksnių valdymas.

Tyrimo tikslas: įvertinus ergonominių rizikos veiksnių valdymą komercinės įmonės darbo aplinkoje pasiūlyti prevencinių priemonių, kurios padètų gerinti situaciją.

Tikslui pasiekti keliami uždaviniai: teoriniu aspektu apibūdinti rizikas darbo aplinkoje ir ergonominiu rizikos veiksnių valdymo reikšmę jas sprendžiant. Komercinès įmonės darbo aplinkoje įvertinti ergonominių rizikos veiksnių valdymą. Pateikti galimas prevencines priemones.

Mokslinio tyrimo metodai: mokslinès literatūros loginè ir sisteminè analizė; statistinių duomenų kaupimas ir jų analizé; lyginamoji analizé; tyrimo duomenų grupavimas, gauti tyrimo rezultatai apdoroti naudojant MS Excel programą.

\section{Darbo aplinkos reikalavimai ir ergonominių rizikos veiksnių poveikio valdymas}

Norint užtikrinti ilgalaikę verslo sẻkmę, reikia turèti veiksmingą vadybos sistemą, kuri apimtų visus imonės valdymo ir veiklos elementus (Zakarevičius 2003; Seilius ir kt., 2004; Giedraitis, 2009; Kaminskas ir Jagniatinskis, 2012).

Kadangi įmonių vystymąsi ypač veikia naujausios technologijos ir kintančios ekonominès bei socialinès sąlygos, darbo vietos, darbo aplinka, darbo praktika ir gamybos procesai įmonėse nuolat keičiasi. Naujos darbo aplinkybès sukelia naują riziką ir problemas, kurioms spręsti reikia politinio, administracinio ir techninio pobūdžio priemonių. 
Saugi darbo aplinka leidžia žmogui optimaliai funkcionuoti, skatina jo darbingumą, lemia darbo rezultatų kokybę ir pasitenkinimą pačiu darbu (Seilius ir kt., 2004). Dažni atvejai, kai įmonės patiria milijoninius nuostolius vien dèl to, kad mažai dėmesio skyrè sveikatai stiprinti, kenksmingų sveikatai veiksnių prevencijai. Todèl didèja nedarbingumo lygis, tai lemia nelaimingi atsitikimai ir ligos, daugèja pravaikštų, mažejja našumas ir kokybė, didejja darbuotojų kaita, kartu ir bendrosios jų apmokymo išlaidos. Bendra kokybès, aplinkos, darbuotojų saugos ir sveikatos vadybos sistema ịmonėje leidžia pasiekti naują atsakingo verslo lygị. Todèl kiekvieno darbuotojo darbo vieta turi būti saugi, patogi ir nekenksminga sveikatai, ịrengta pagal darbuotojų saugos ir sveikatos norminių teisès aktų reikalavimus. Darbo aplinkoje nustatytos įvairios rizikos ir jų poveikis darbuotojams turi būti valdomi.

Valdymo aspektu, kaip teigia L. Baronienè (2008), analizuodama mokslinę literatūrą pastebejjusi, kad kiekviena įmonė neišvengiamai susiduria su rizikos veiksniais darbo aplinkoje. Valdymo procesas yra gana sudètingas, nes būtina nuolat analizuoti organizacijos veiklą: diagnozuoti vykstančius pokyčius, juos inicijuoti ir atitinkamai valdyti. Būtina suvokti veiklos valdymo svarbą ir veiksmingai to siekti, priešingu atveju organizacija gali patirti fiasko (Lodienè, 2005). Tokios rizikos valdymas yra ūkio subjektų veiksmai, apimantys procedūrų ir priemonių, skirtų nuostolio atsiradimo tikimybei ir (arba) įvykio metu atsiradusių nuostolių sumažinimui, numatymą ir ịgyvendinimą (Čepinskis, Raškinis, 2005).

E. Buškevičiūtès ir A. Leškevičiūtès (2008) teigimu, rizikos valdymo procesą sudaro penki pagrindiniai etapai, kurie yra glaudžiai tarpusavyje susiję:

- rizikos planavimas;

- rizikos identifikavimas;

- rizikos įvertinimas;

- rizikos valdymo priemonių parinkimas;

- rizikos kontrolè.

Ergonominiai rizikos veiksniai apibūdinami darbo sunkumą sudarančių veiksnių parametrais ir darbo itampos veiksnių rodikliais. Ergonominiai rizikos veiksniai darbo aplinkoje sąveikauja tarp darbo vietos ir darbuotojo. Be to, tai darbo vietos parametrų ir darbuotojo antropometrinių duomenų bei galimybiu atitikimas. Fizinis darbo krūvis, itampa, darbo vietos projektavimas pagal darbuotojo galimybes sudaro ergonominio veiksnio pagrindą (Seilius, 2004). Ergonominių rizikos veiksnių analizavimas darbo vietoje yra naudingas, nes padeda išspręsti problemas, kurios susijusios su darbo sąlygų gerinimu, darbo įrangos ir ịrankių projektavimu (Juonytė, 2011). Neužtikrintas saugumas neigiamai veikia vadovų ir darbuotojų sveikatą, mažina bendrą pasitenkinimą darbu. Virpesiai, triukšmas, skleidžiami mechanizmų, mašinų ar ịrenginių, priskiriami pavojingiems fiziniams veiksniams darbo vietoje. Šiai grupei priklauso ir tokie veiksniai kaip šaltis, karštis, oro drègmè. K. A. Kaminskas ir J. Antanaitis (Kaminskas, 2007; Kaminskas, Antanaitis, 2010) išskyre šiuos ergonominius rizikos veiksnius: naudojama jèga; pasikartojantys judesiai; darbo poza; vietiniai sąlyčio įtempimai; vibracija; oro temperatūra; triukšmas; prastas apšvietimas. Pagrindinis teisinis dokumentas, reglamentuojantis ergonominių rizikos veiksnių vertinimą, yra „Ergonominių rizikos veiksnių tyrimo metodiniai nurodymai, patvirtinti Lietuvos Respublikos sveikatos apsaugos ir Lietuvos Respublikos socialinès ir darbo apsaugos ministerijos $2005 \mathrm{~m}$. liepos $15 \mathrm{~d}$. ịsakymu“. İsakyme nustatyta ergonominių rizikos veiksnių vertinimo įmonèje tvarka ir nurodytos bendros prevencijos dèl darbuotojų apsaugos nuo rizikos jų sveikatai ir saugai, kurią gali lemti ergonominiai veiksniai, priemonès.

Siekiant sumažinti neigiamą rizikos veiksnių poveikị, parinkti tinkamas prevencines priemones, būtina kiekvienoje darbo vietoje atlikti rizikos veiksnių tyrimą ir analizę (Seilius, 2004; Kaminskas, 2007). Svarbiausia, kad darbo vieta būtų pritaikyta konkrečiam asmeniui o ne atvirkščiai (Andruškevičiūtè, 2008). Darbo vieta turi būti pritaikyta darbuotojui, atsižvelgiant ị jo darbo pobūdị ir naudojamus ịrenginius. Darbas darbo vietoje dažnai suprantamas kaip vykdoma užduotis ir darbo aplinkos reikalavimai (Taveira, Smith, 2011). Darbo aplinka apibrèžiama kaip darbo vietos erdvė, kurioje gali veikti darbuotojo sveikatai kenksmingi, pavojingi rizikos veiksniai (fiziniai, fizikiniai, cheminiai, biologiniai ir kt.) (Žin., 2002, Nr. 87-3751). 
Remiantis „Darbuotojų saugos ir sveikatos ịstatymo nuostatomis“ (Žin., 2003, Nr. 70-3170, darbo sąlygu samprata apima darbo aplinką, darbo pobūdị, darbo ir poilsio laiką bei kitas aplinkybes, kurios tiesiogiai veikia darbuotojo savijautą, darbingumą, saugą ir sveikatą. Profesinès rizikos vertinimo tvarką ịmonejje ar įstaigoje reglamentuoja „Profesinès rizikos vertinimo nuostatai“ (Žin., 2003, Nr. 100-4504). Pagal šiuos reikalavimus įmonių veikla turi būti saugi ir patikima dirbantiems bei aplinkiniams žmonèms. Todèl nustatydama ir peržiūrèdama savo tikslus, įmonè turi vadovautis teisiniais ir kitais reikalavimais, atsižvelgti ị galimą riziką ir pavojus darbuotojų saugai bei sveikatai, technologijos galimybes, finansinius, veiklos ir verslo reikalavimus bei suinteresuotujų šalių požiūrị.

Todèl norint išvengti rizikos ar bent sumažinti ergonominių rizikos veiksnių neigiamą poveiki ịmonès darbuotojams, privalu ịvertinti kiekvieną darbo vietą. Nustačius galimą ergonominių veiksnių riziką, ji turi būti kuo greičiau pašalinta arba sumažinta, vadovaujantis profesinès rizikos vertinimo nuostatais. İmonès vadovas ar jo pavedimu darbdavio ịgaliotas asmuo, siekdami užtikrinti darbuotojų saugą ir sveikatą, organizuoja techninių, organizacinių ir kitų priemonių, kurios skirtos mažinti ar šalinti ergonominių veiksnių keliamą riziką, rengimą ir igyvendinimą. Būtina sistemiškai analizuoti nustatytus pavojus, rizikas ir incidentus. Tuo siekiama: didesnio informuotumo apie pavojus ir rizikas darbo vietose; vidinių procesų skaidrumo; geresnio darbuotojų komunikavimo; didesnio darbuotojų motyvavimo ir organizacijos rẻmimo; integruoto požiūrio ị darbo aplinką; geresnių priemonių, kurios padètų igyvendinti darbo saugos ir sveikatos reikalavimus.

Nors dauguma autorių moksliniuose šaltiniuose pabrèžia finansinių išteklių svarbą, P. Zakarevičius (2009) akcentuoja, kad fundamentalusis organizacijų veiklos ir tobulejjimo išteklius yra ir bus informacija bei žinios apie galimus technologijų, vartotojų poreikių, gamtos aplinkos, darbuotojų mąstymo pokyčius, todèl naujų žinių igijimas ir jų kūrimas tampa pagrindiniu efektyvios veiklos veiksniu. Todèl viena iš ergonominių rizikos veiksnių prevencijos kultūros stiprinimo krypčių turi būti naujų rizikų, susijusių su technine pažanga ar socialiniais pokyčiais, nustatymas, atliekant mokslinius tyrimus ir renkant informaciją apie naujas rizikas. Puoselèti prevencinę kultūrą galima gerinant darbuotojų švietimą ir informavimą apie galimas rizikas, tobulinant galiojančių teisès aktų taikymą. A. Kubrak ir kt. (2007) mini, kad šiuolaikinei įmonei, ieškančiai naujų valdymo svertų, labai svarbu išnaudoti žinių visuomenèje sparčiai tobulëjančių informacinių technologijų, didèjančios naujų žinių diegimo spartos privalumus. Šiame procese ypač reikšmingas įmonès žmogaus išteklių formavimo, ugdymo sistemos tobulinimas. Mokant asmenis profesijos ar atitinkamos specialybès turi būti mokoma nustatyti specifines rizikas, su kuriomis būsimasis darbuotojas susidurs darbe. Mokymas ir informavimas apie rizikas turi prasidèti ne tada, kai žmogus pradeda darbinę veiklą, bet tai turi būti visų lygių mokyklų mokymo programų sudètinè dalis. Mokant asmenis profesijos ar atitinkamos specialybės turi būti mokoma nustatyti specifines rizikas, su kuriomis būsimasis darbuotojas susidurs darbe.

Imonèse ergonominių rizikos veiksnių valdymas yra kolektyvinis darbas, kurị turi atlikti vidaus arba išorès specialistai. Imonėse specialistai, atliekantys ergonominių veiksnių rizikos tyrimus, turi turèti žinių apie riziką ir pavojus, kurių atsiranda dèl ergonominių veiksnių keliamos rizikos darbuotojų sveikatai, būti susipažinę su teisès aktais, reikalavimais, standartais ir metodikomis, kurie susiję su ergonominių veiksnių rizikos nustatymu. Samdomos įstaigos ir specialistai turi tureti teorinių ergonominių veiksnių rizikos vertinimo žinių (aukštajj išsilavinimą liudijančius diplomus ir profesinès rizikos veiksnių vertinimo [tyrimo, nustatymo] tobulinimosi kursų sertifikatus). Nustačius ergonominius rizikos veiksnius, sudaromi rizikos vertinimo objektų (darbo vietų) sąrašai. Todèl siekiant procesinio valdymo, svarbu, kad šis procesas susietu materialinius, finansinius ir intelektinius išteklius (tarp jų ir žmogiškuosius) bei veiklas, kurie būtini siekiant rezultato. Dažnai vieno proceso rezultatas yra kito proceso gavinys. Rezultatas pasiekiamas daug efektyviau, kai veikla ir su ja susiję ištekliai yra valdomi kaip vientisas ir pakartojamas procesas ar jų sistema (Seilius, 2004; Giedraitis, 2009; Klimas ir Ruževičius, 2009). Konkreti ERV grèsmė gali paveikti konkrečias veiklos sritis ir sukelti nepageidaujamus padarinius.

Todèl vienas galimų pasiūlymų tvarkant darbo aplinką įmonèje - suformuluoti ir pateikti ergonominių rizikos veiksnių valdymo etapų turinị. 
1 lentele. Ergonominių rizikos veiksnių (ERV) valdymo etapų turinys

\begin{tabular}{|c|c|}
\hline Valdymo funkcijos & Veiklos aprašymas \\
\hline $\begin{array}{l}\text { Planavimas } \\
\text { Tai organizacijos pasirengimas valdyti } \\
\text { ERV. Šiame procese parenkamos } \\
\text { prevencinès priemonès ir nustatoma } \\
\text { veiksmų seka. Svarbu, kad ERV valdymo } \\
\text { priemonių sąnaudos būtų mažesnès nei } \\
\text { pačios rizikos sukelti nuostoliai }\end{array}$ & $\begin{array}{l}\text { Imonės vadovas turi planuoti ergonominių rizikos veiksnių vertinimą ir ị } \\
\text { galimos ergonominių veiksnių rizikos nustatymo procesą įtraukti įmonės } \\
\text { darbuotojus } \\
\text { Darbuotojai turi prisidèti prie techninių priemonių ir materialinių išlaidų } \\
\text { planuojant esamų / numatomų ergonominių rizikos veiksnių šalinimą; } \\
\text { Prevencinès priemonės turi būti planuojamos visuose veiklos etapuose, } \\
\text { atsižvelgiant ị çmonės aplinką, sąlygas, išteklius }\end{array}$ \\
\hline $\begin{array}{l}\text { Organizavimas } \\
\text { Nustatomi (parenkami) asmenys, } \\
\text { atsakingi už tam tikras veiklos sritis, } \\
\text { kuriose nustatyta kenksmingų ir } \\
\text { pavojingų ERV, ir taikomų prevencinių } \\
\text { priemonių efektyvumą }\end{array}$ & $\begin{array}{l}\text { İmonės vadovas (arba jo igaliotas asmuo) organizuoja techninių, } \\
\text { organizacinių ir kitų priemonių, kurios skirtos ergonominių rizikos veiksnių } \\
\text { keliamai rizikai mažinti ar šalinti, rengimą ir ígyvendinimą } \\
\text { Vadovai i̇ ịmonę priima atsakingą ERV valdymo specialistą (arba samdo } \\
\text { specialistus), kurių patirtis padètų valdyti galimą darbo vietos riziką } \\
\text { İmonès vadovas paskirsto atsakomybę už ergonomišką darbo aplinkos } \\
\text { įrengimą ir ergonominių rizikos veiksnių poveikio darbuotojams mažinimą } \\
\text { bei šalinimą taikant prevencines priemones }\end{array}$ \\
\hline $\begin{array}{l}\text { Vadovavimas ir motyvavimas } \\
\text { Tinkamas atsakingų asmenų vadovavimo } \\
\text { stilius ir parinktos motyvavimo } \\
\text { priemonès turi garantuoti tinkamą } \\
\text { prevencinių priemonių taikymą bei ERV } \\
\text { valdymą }\end{array}$ & $\begin{array}{l}\text { Vadovai (skyrių, padalinių, barų ir kt.) supažindina darbuotojus su įmonės } \\
\text { nustatytomis procedūromis } \\
\text { Vadovai (skyrių, padalinių, barų ir kt.) tinkamai motyvuoja darbuotojus } \\
\text { naudotis asmeninėmis ir kolektyvinėmis apsaugos priemonemis, siekiant } \\
\text { sumažinti arba pašalinti ERV poveikị } \\
\text { Darbinės veiklos reikalavimai turi atitikti vadovų ir darbuotojų gebejjimus }\end{array}$ \\
\hline $\begin{array}{l}\text { Kontrolė } \\
\text { Nustačius, kad prevencinės priemonės } \\
\text { naudojamos netinkamai, svarbu atlikti } \\
\text { atitinkamą korekciją, kad atsiradę } \\
\text { nukrypimai neiškraipytų ERV valdymo } \\
\text { proceso }\end{array}$ & $\begin{array}{l}\text { Imonės vadovas (arba jo igaliotas asmuo) nustato vidinės kontrolės tvarką, } \\
\text { remdamasis parengtais ir patvirtintais lokaliniais teisės aktais } \\
\text { Vadovai (skyrių, padalinių, barų ir kt.) turi kontroliuoti kintančias darbo } \\
\text { sąlygas ir prevencinių priemonių taikymo veiksmingumą } \\
\text { Imonès vadovas turi tikrinti, ar laikomasi planavimo etape nustatytos } \\
\text { saugaus darbo praktikos, ar ergonominių rizikos veiksnių prevencijai } \\
\text { tinkamai naudojami materialiniai ištekliai }\end{array}$ \\
\hline
\end{tabular}

Pateiktas ergonominių rizikos veiksnių valdymo etapų turinys padès sistemiškai ir patikimai valdyti riziką, kuri kyla arba gali kilti dèl nepakankamo procesų valdymo, prastos kokybès, galimų avarinių situacijų ir nelaimingų atsitikimų. Teigtina, kad planuojant, organizuojant, vadovaujant (motyvuojant), kontroliuojant, būtina laikytis modernių principų, kurie užtikrina valdymo mobilumą, lankstumą, demokratiškumą, antrepreneriškumą ir kitus modernių organizacijų vadybos instrumentus. Kenksmingų ir pavojingų ergonominių veiksnių prevencijos valdymas darbo vietoje padeda stiprinti darbuotojų sveikatą. Sveiki darbuotojai užduotis atlieka kokybiškiau ir yra produktyvesni. Tai padeda mažinti nedarbingų dienų skaičių. Todèl galima teigti, kad saugios ir sveikos darbo sąlygos yra esminis darbo kokybès elementas.

Apibendrinant galima teigti, kad ergonominių rizikos veiksnių valdymas padeda užtikrinti įmonès veiklos efektyvumą ir svarbiausio įmonès ištekliaus - darbuotojo sveikatos bei darbingumo - išsaugojimą, vadovams sužinoti realią darbų saugos ir darbo sąlygų būklę bei pagerinti darbo sąlygas. Norint išvengti rizikos ar bent sumažinti rizikos veiksnių neigiamą poveikį įmonès darbuotojams, labai svarbu ir privalu įvertinti kiekvieną darbo vietą, surasti trūkumų, parinkti prevencinių priemonių ir valdyti ergonominių rizikos veiksnių poveikị. Visos iniciatyvos turi būti praktiškai pritaikomos, atsižvelgiant ị kainą ir sudètingumą. Todèl ergonominių rizikos veiksnių poveikio įmonėse valdymas galètų tapti veiksmingu nelaimingų atsitikimų darbe ir susirgimų profesinèmis ligomis mažinimo būdu, kartu sumažinti organizacinio pobūdžio pažeidimus mūsų šalies įmonèse. 


\section{Ergonominių rizikos veiksnių valdymo komercinèje įmonėje tyrimas ir rezultatų analizé}

Tyrimu siekiama statistiškai apibūdinti esminius objekto požymius, tai yra įvertinti ergonominių rizikos veiksnių valdymą įmonès darbo aplinkoje ir pasiūlyti prevencinių nustatytų valdymo problemų sprendimo priemonių.

Tyrimo metodologija. Tiriama komercinè įmonè ịkurta 1993 m., Lietuvos rinkoje ji veikia jau 20 metų. Imonė savo veiklą pradèjo Klaipėdos apskrityje ir šiuo metu turi filialus Vilniuje, Kaune bei devyniuose mažesniuose Lietuvos miestuose, kurie tiekia prekes didiesiems prekybos tinklams. İmonės pavadinimas vadovo prašymu neskelbiamas.

Tyrimo tipas - kiekybinis, aprašomasis. Tyrimo metodas - anketiné apklausa. Taikyta anoniminè apklausa, pateikiant uždaruosius, atviruosius ir mišriuosius klausimus. Anketos kokybė, objektyvumas ir teisingas tikrovès atspindys labai priklauso nuo klausimų pateikimo teisingumo. Klausimų turinys, jų formulavimas, eiliškumas ir tarpusavio ryšys anketoje turi atitikti tam tikrus reikalavimus. Todẻl sudarinejjant anketos klausimus laikytasi R. Tidikio (2003) nustatytų reikalavimų. Klausimų sąrašas sudarytas trumpam tyrimui apie imonès darbo aplinką atlikti.

Apklausa vyko 2013-05-01-2013-05-05 dienomis. Su įmonès vadovu iš anksto suderintas vertintojo atvykimas, siekiant atlikti ergonominių rizikos veiksnių valdymo darbo aplinkoje tyrimą. Taip užtikrintas darbuotojų buvimas darbo vietoje ir netrukdoma jiems atlikti savo pareigas. Anketos, kuriose pateikta 12-a klausimų (žr. 1 lentelę), įteiktos asmeniškai kiekvienam darbuotojui. Anketinei apklausai atlikti skirta viena valanda laiko. Reikia pastebèti, kad kiekybinio tyrimo duomenys rinkti dalyvaujant visiems respondentams, todẻl pažymėtina tyrimo atlikimo administravimo ypatybė: respondentai turèjo galimybę išsiaiškinti jiems neaiškius anketos klausimus. Siekiant šiame tyrime sumažinti riziką, kad apklausiamieji sąmoningai ar nesąmoningai nepateiktų konformistinių atsakymų, orientuotųsi ne tiek ị klausiamo dalyko esmę, kiek ị viešają nuomonę ir jos deklaruojamas dorovės normas, taikyta S. Vaitkevičiaus (2006) rekomenduojama psichometrinè statistika, kuri padeda užtikrinti apklausos validumą (tinkamumą) ir reliabilumą (patikimumą).

Toks anketos administravimo pobūdis galëjo būti vienas iš veiksnių, užtikrinančių vidinio instrumento (anketos) patikimumo (validumo) prielaidas, kadangi atlikus statistinę patikrą nustatyta, kad kronbacho alfa reikšmė (rodanti vidinị instrumento patikimumą jo klausimų atžvilgiu) lygi 0,867. Alfa dydžio svyravimas iki 1 rodo, kad duomenų patikimumas yra svarus ir arteja prie idealaus rodiklio. Remiantis R. Gliem ir J. Gliem (2003), kai alfa rodiklis: $>0,9$ - idealus; $>0,8-$ stiprus; $>0,7$ - priimtinas; $>0,6$ - abejotinas; $>0$, 5 - silpnas; $<0,5$ - nepriimtinas.

Respondentai. Tyrime dalyvavo 60 respondentų: vyrai sudare 71,7 proc. $(n=43)$, moterys $-28,3$ proc. $(n=17)$. Tai komercinès įmonès darbuotojai, dirbantys centrinëje būstinèje, Kretingos rajone.

Pagal išsilavinimą respondentai pasiskirste taip: vidurinị išsilavinimą turi 27 proc. respondentų, profesinị - 46 proc., aukštaji neuniversitetini -20 proc., aukštaji universitetini -7 proc. Tai rodo, kad tyrime dalyvavę respondentai yra išsilavinę ir geba tinkamai atsakyti ị pateiktus klausimus.

Respondentai nurodè tokị savo amžių: $18-25 \mathrm{~m}$. - 32 proc. respondentų; $26-35 \mathrm{~m}$. -45 proc. respondentų; $36 \mathrm{~m}$. ir daugiau -23 proc. respondentų. Respondentų amžiaus vidurkis - 35 metai. Taigi galime teigti, kad kolektyvas yra jaunas ir patyręs. Jauna ir dinamiška bendrovès darbuotojų komanda lengvai perima naujausias technologijas ir sėkmingai jas taiko kasdieniame darbe. Šis kolektyvas žino ir supranta darbo aplinkai keliamus reikalavimus.

Respondentai pagal darbo stažą pasiskirste taip: mažiau nei 1 metus darbo stažo turi 38 proc.; nuo 1 iki 5 metu -42 proc.; daugiau kaip 5 metus -20 proc.

Tyrimo rezultatai. Išanalizavus apklausos anketų duomenis pastebėta, kad vertinant ergonominių rizikos veiksnių valdymą (pagal penkių balų skalę) respondentų vidutinis vertinimo balas nedidelis. Manytina, kad problemų nagrinejjamais klausimais kyla. 
Pirmame paveiksle pateikti tyrimo pagal amžiaus grupes rezultatai atskleidžia, kad daugiausia trūkumų nustatyta grupeje vadovavimas diegiant prevencines priemones ir motyvuojant naudoti prevencines priemones. Ypač tuo nusivylę vyresni nei 36 metų respondentai. Jų vertinimo balas mažiausias - 2,93 balo (1 pav.).

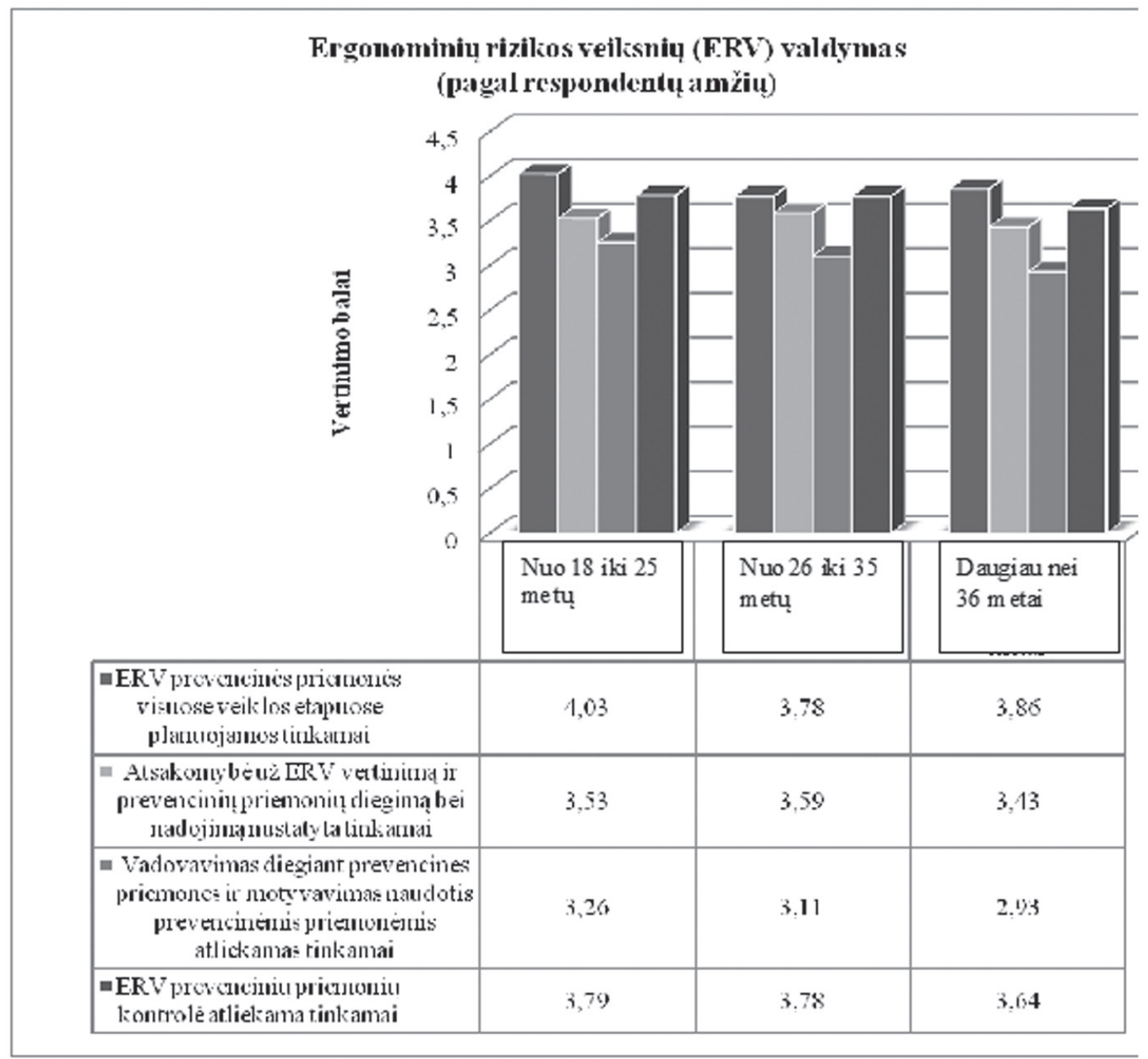

1 pav. Ergonominių rizikos veiksnių valdymo tinkamumas

Anketinès apklausos duomenys atskleidè (1 pav.), kad vyresni įmonės darbuotojai norètų, kad vadovai daugiau dėmesio skirtų darbo aplinkai - taikytų prevencines priemones ir motyvuotų juos (darbuotojus) taikyti šias priemones šalinant ergonominius rizikos veiksnius ir jų poveikį. Todėl vadovai savo vadovavimo stilių turètų kreipti ị rūpinimąsi žmonėmis, siekti darbuotojams sudaryti palankias ir sveikas darbo sąlygas. Jų (vadovų) veikla - valdymo uždavinių sprendimas, remiantis specifiniais savo gebejjimais nukreipti, stimuliuoti ir sutelkti visų įmonés narių pastangas bendram įmonés labui. Veiksmingas vadovavimas siekiant imonès tikslų padeda sukurti dalyvavimo ir kolektyvizmo atmosferą. To rezultatas - kyla darbuotojų darbo našumas ir gerèja ịmonès darbo rezultatai.

Kaip matome 2 paveiksle, respondentai, atsižvelgiant ị jų darbo stažą, ergonominių rizikos veiksnių valdymą vertina skirtingai. Planuojant prevencines priemones mažą darbo stažą turintys darbuotojai ergonominių rizikos veiksnių valdymą vertina tik 2,91 balo. O turintieji didesnį kaip 5 metų darbo stažą $-4,75$ 
balo. Tai rodo netinkamą naujų darbuotojų adaptaciją ir menką jų ịtraukimą ị planavimo procesą parenkant prevencines ergonominių rizikos veiksnių poveikio mažinimo ar šalinimo priemones. Nes darbuotojų skatinimas bendradarbiauti, suteikiant jiems galimybę dalyvauti priimant svarbius sprendimus, kurie susiję su jų darbo aplinka, didina ịsipareigojimą ịmonei, motyvaciją dirbti ir bendrą ịmonès produktyvumą.

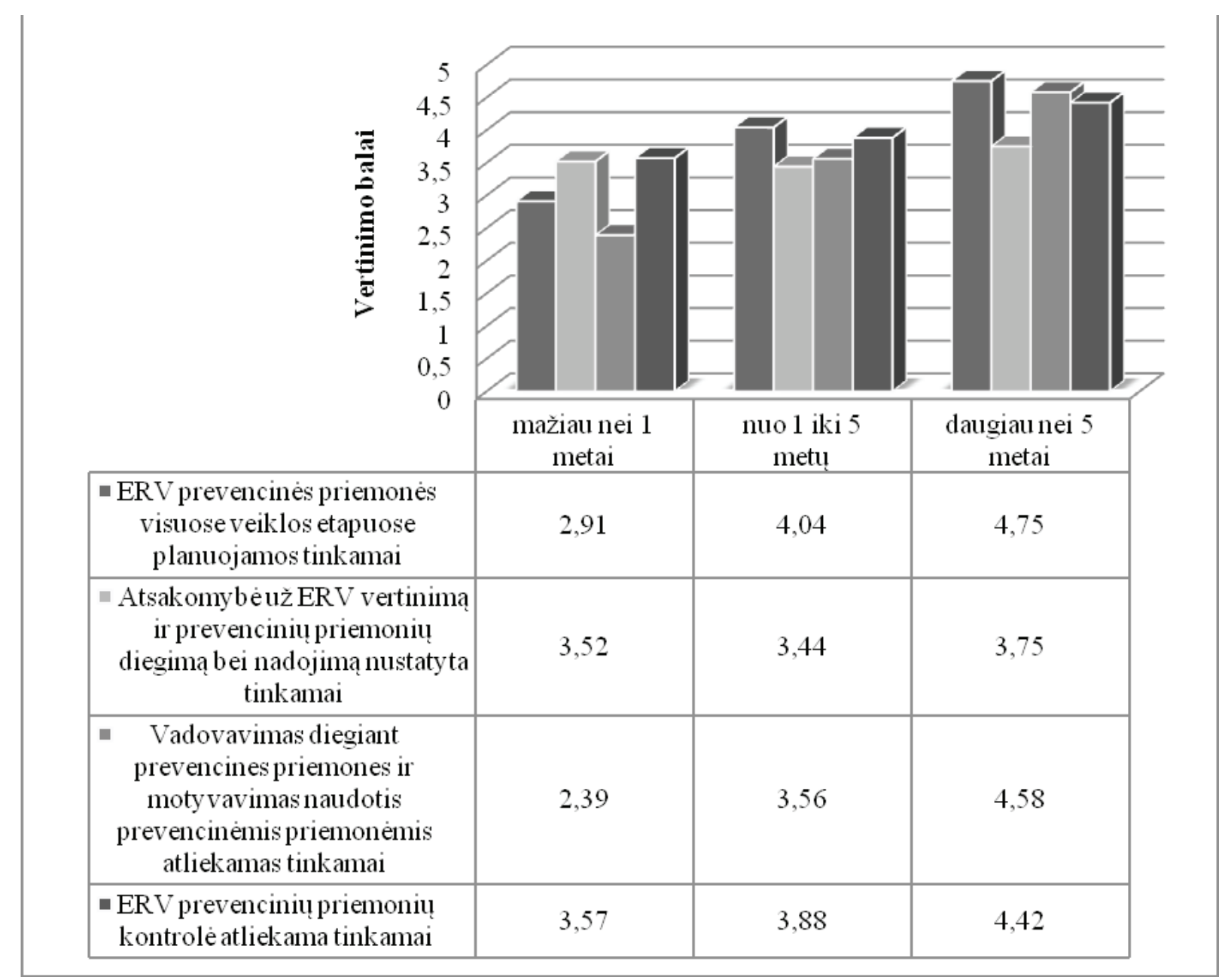

2 pav. Respondentų ergonominių rizikos veiksnių valdymo vertinimas, atsižvelgiant ị darbo stažą

Tyrimo rezultatai, pateikti 2 paveiksle, rodo, kad vadovai, taikydami prevencines priemones ir motyvuodami darbuotojus jas taikyti, netinkamai vadovauja tiems darbuotojams, kurių darbo stažas yra iki vieneriu metų (2,39 balo). Tai patvirtina respondentai, kurių darbo stažas didesnis nei 5 metai, nes jų vertinimas labai aukštas $-4,58$ balo. Pastarieji darbuotojai gerai supranta tai, ką dirba, be to, jų turimų žinių taikymas pasitelkus motyvaciją duoda teigiamą efektą pačiam darbuotojui, kartu ir įmonei. Vadovas, siekiantis ilgalaikès sėkmès, turi suderinti skirtingas pažiūras, neužmiršdamas darbuotojų poreikių, nes to nepaisymas paveiks bendro darbo kokybę, motyvaciją, kitaip tariant, užduotis gali likti neigyvendinta. O kiekvienos įmonès tikslas - ịvykdyti nustatytas užduotis, kartu sudaryti palankias darbo sąlygas darbuotojams. Vadovas turi nuspręsti, kokie pokyčiai darbo aplinkoje būtini, siekiant didinti darbuotojų indèlị ị ịmonès veiklą.

Gauti tyrimo rezultatai atskleidžia, kad įmonès nariai suvokia ergonominių rizikos veiksnių valdymo darbo aplinkoje reikšmę. Remiantis gautais tyrimo rezultatais, įmonei svarbias valdymo problemas reikia taip spręsti: 
- periodiškai atlikti ergonominių rizikos veiksnių valdymo analizę;

- informuoti (nuolat) naujus ir patyrusius darbuotojus apie pasikeitusias darbo sąlygas bei įmonèje planuojamas arba diegiamas prevencines priemones, taip užtikrinant informacijos prieinamumą;

- sudaryti tinkamas sąlygas darbuotojams tobulèti (seminarai, kursai), teikti jiems reikalingas žinias ergonominiais klausimais;

- užtikrinti visų darbuotojų dalyvavimą sprendžiant ergonominių rizikos veiksnių valdymo klausimus.

İmonès vadovas, kuris daugiau dėmesio skiria ergonominių rizikos veiksnių valdymui, ne tik išvengia didelių išlaidų dèl darbuotojų nedarbingumo, bet ir padidina įmonejje veiklos produktyvumą. Vadovo ir darbo aplinkos sąveika būtina siekiant ịmonès tikslų.

Todèl ergonominių rizikos veiksnių poveikio įmonėms valdymas galètų tapti veiksmingu nelaimingų atsitikimų darbe ir susirgimų profesinèmis ligomis mažinimo būdu, kartu sumažintų organizacinio pobūdžio pažeidimus ne tik regione bet ir šalies įmonėse.

\section{Išvados}

Teorinė mokslinès literatūros analizė atskleidè, kad siekiant išvengti rizikos ar bent sumažinti rizikos veiksnių neigiamą poveikị ịmonès darbuotojams, būtina tiksliai valdyti ergonominių veiksnių riziką, kuri gali kilti dèl nepakankamo procesų valdymo, kokybès, galimų avarinių situacijų, nelaimingų atsitikimų. Šj tikslą galima pasiekti ịvairiomis prevencinèmis priemonėmis, tik nereikètų pamiršti, kad ergonominių rizikos veiksnių valdymo procedūros pagrịstos ergonominių rizikos veiksnių vertinimu, prioritetais, dèmesys sutelktas ị verslo įmonès darbuotojų saugai svarbius aspektus. Tačiau kiekviena įmonè, rengdama nelaimingų atsitikimų prevencijos priemonių planą, turi atsižvelgti ị bendrą įmonės aplinką, sąlygas ir turimus išteklius.

Atliktu tyrimu nustatyta, kad reikia ne tiek gerinti darbo sąlygas, bet ir suteikti žinių darbuotojams apie naudojamas prevencines priemones, jų taikymo tikslingumą ir teikiamą naudą tiek darbuotojui, tiek įmonès rezultatams. Iš didesnị darbo stažą turinčių darbuotojų vertinimo sužinota, kad ịmonė rūpinasi savo darbuotojų darbo aplinka ir skiria tam (nors ir minimaliai) lěšų. Kita vertus, iš nesenai pradejjusių dirbti ir nedideli darbo stažą turinčių darbuotojų gauta informacija verčia tobulinti vadovavimo ir motyvavimo procesą: būtina keisti atsakingų darbuotojų (ypač specialistų, vadovų, darbdavių) požiūrị i darbą su neseniai pradejusiais dirbti bei nedidelị darbo stažą turinčiais darbuotojais, keliant aukštus reikalavimus adaptacijos procesui; svarbu, kad už tai atsakingi įmonès darbuotojai laiku pastebètų darbuotojų lūkesčius, privalumus, galimybes ir ribotumus įvairiose tikslingos veiklos srityse.

Praktinis tyrimas įmoneje parodè, kad apklaustiems tyrimo dalyviams ergonominiai reikalavimai darbo aplinkoje yra svarbūs. Manytina, kad ergonominių rizikos veiksnių valdymas taps įmonès veiklos dalimi ir padès tobulinti ne tik tirtos įmonès, bet ir rinkos, kurioje veikia ši įmonè, rizikos valdymo procesą. Todèl siekiant didinti darbuotojų indèlị ị įmonès veiklą, ergonominių rizikos veiksnių poveikio įmonèse valdymas turi tapti veiksmingu nelaimingų atsitikimų darbe ir susirgimų profesinėmis ligomis mažinimo būdu, kartu būtų šalinami organizacinio pobūdžio pažeidimai. Tokia praktika leis darbuotojams dirbti palankiomis jų sveikatai darbo sąlygomis, gerès jų darbo našumas ir įmonès darbo rezultatai.

\section{Literatūra}

Andriuškevičiūtè, L. (2008). Darbo pozų ir krovinių tvarkymo rankomis UAB „Rezetas“ tyrimas. Konferencijos ,,Mokslas - Lietuvos ateitis “, vykusios Vilniuje 2008 m. balandžio 2-4 d., straipsniu rinkinys, p. 585-591.

Bagdonienė, D., Paulavičienė, E. (2010). Socialinės atsakomybės ir organizacijos vadybos sistemos integravimas. Ekonomika ir vadyba [Economics and Management], nr. 15, p. 366-373. 
Baronienè, L. (2008). Teorinès prielaidos inovacinès aplinkos kūrimui. Vadybos mokslas ir studijos - kaimo verslu ir ju infrastruktūros plètrai, nr. 13 (2), p. 23-31.

Buškevičiūtė, E., Leškevičiūtė, A. (2008). Rizikos valdymas draudimo įmonèse. Taikomoji ekonomika: sisteminiai tyrimai, nr. 2, p. 59-79.

Čepinskis, J., Raškinis, D. (2005). Draudimo veikla. Kaunas: VDU.

ESENER 2009 metu ataskaita. Europos ịmoniu apklausa apie naują kylančią rizika. (2009). Prieiga internete: <http:// osha.europa.eu/lt/riskobservatory/enterprise-survey/enterprise-survey-esener> [žiūrèta 201307 11].

Gliem, J. A., Gliem, R. R. (2003). Calculating, interpreting, and reporting Cronbach's Alpha reliability coefficient for Likert-type scales. Paper presented at the 2003 Midwest Research-to-Practice Conference in Adult, Continuing, and Community Education. Columbus, OH. Prieiga internete: https://scholarworks.iupui.edu/bitstream/handle/1805/344/Gliem\%20\&\%20Gliem.pdf?sequence $=1$

Giedraitis, A. (2009). Vadovavimo praktika. Tiltai, nr. 2 (47), p. 95-111.

Juonytė, I. (2011). Ergonominių rizikos veiksnių UAB „Ukmergès gelžbetonis“ analizè. Mokslas - Lietuvos ateitis. 2011 metu temines konferencijos ,,Statyba“ (2011 m. kovo 23-25 d.) straipsniu rinkinys. Vilnius: Technika, p. 1-6.

Kaminskas, K. A. (2007). Ergonominių rizikos veiksnių valdymo Lietuvoje strategija. Sveikatos mokslai, nr. 7 (54), p. 1427-1432.

Kaminskas, K. A., Antanaitis, J. (2010). A cross-sectional survey of construction workers: an ergonomic approach. The 10th Internetional Conference „Modern Building Materials, Structures and Techniques“, May 19-21, 2010, Vilnius, Lithuania. Vilnius: Technika, p. 1246-1252.

Kaminskas, K. A., Jagniatinskis, A. (2012). Triukšmo poveikio darbo aplinkoje naujos įvertinimo ir valdymo galimybès. Sveikatos mokslai, nr. 3, p. 98-101.

Kardelis, K. (2007). Mokslinių tyrimu metodologija ir metodai. Šiauliai: Lucilijus.

Klimas, D., Ruževičius, J. (2009). Procesinio valdymo ir pokyčių diegimo organizacijoje metodologiniai aspektai. Verslo ir teisés aktualijos, nr. 2, p. 72-87.

Kubiliūtė, G., Kaminskas, K. A. (2011). Kelių statybos įmonių ergonominių ir psichosocialinių rizikos veiksnių tyrimas. Mokslas - Lietuvos ateitis. 2011 metu teminés konferencijos ,,Statyba“ (2011 m. kovo 23-25 d.) straipsniu rinkinys. Vilnius: Technika, p. 1-5.

Kubrak, A., Koval, K., Kavaliauskas, V., Sakalas, A. (2007). Organizational Structure Forming Problems in Modern Industrial Enterprise. Engineering Economics, no. 1(51), p. 103-109.

Lodienè, D. (2005). Pokyčių samprata ir jų valdymo suvokimas. Organizacijų vadyba: sisteminiai tyrimai, nr. 33, p. 99-109.

LR Darbuotojų saugos ir sveikatos įstatymas (su pakeitimais ir papildymais). (2003). Valstybés žinios, Nr. 70-3170.

Medziukevičiūtė, A., Mieldažys, A. (2010). Darbuotojų saugos ir sveikatos valdymo ypatumai įmonėse. Žmogaus ir gamtos sauga 2010. Tarptautinès mokslinès-praktinès konferencijos medžiaga = Human and nature safety 2010: proceedings of the international scientific conference, p. 39-42.

Ptakauskiene, G. (2008). Ergonominių rizikos veiksnių tyrimo metodų taikymo UAB „HRONAS“ ypatumai. Konferencijos „Mokslas - Lietuvos ateitis“, vykusios Vilniuje 2008 m. balandžio 2-4 d., straipsniu rinkinys, p. $599-607$.

Rwamamara, R. ir kt. (2010). Evidence-based prevention of work-related musculoskeletal injuries in construction industry. Journal of civil engineering and management: international research and achievements, vol. 16, no. 4, p. 499-509.

Seilius, A. ir kt. (2004). Valdymo problemos: teorija ir tendencija. Monografija. KU 1-kla.

Šukys, R. ir kt. (2011). Profesinių ligų ekonominių ir socialinių pasekmių analizė statybos sektoriuje $2005-2010 \mathrm{~m}$. Sveikata, nr. 5, p. 54-59.

Taveira, A. D., Smith, M. J. (2011). Social and Organizational Foundations of Ergonomics. In: G. Salvendy (ed.). Handbook of Human Factors and Ergonomics. 4th edition.

Tidikis, R. (2003). Socialiniu mokslu tyrimu metodologija. Vilnius: LTU Leidybos centras.

Vaitkevičius, S. (2006). Strateginès analizès instrumentarijaus modeliavimas mažose ir vidutinése ịmonèse. Daktaro disertacija. Kaunas: ISM vadybos ir ekonomikos universitetas.

Zakarevičius, P. (2009). Organizacijų ịvairovė ir klasifikavimas. Organizacijų vadyba: sisteminiai tyrimai, nr. 50, p. 127-139 


\title{
MANAGEMENT OF ERGONOMIC RISK FACTORS IN COMMERCIAL COMPANIES
}

\author{
AlgiRDAs Giedraitis \\ Klaipeda University (Lithuania)
}

\section{Summary}

Theoretical analysis of research literature has revealed that prevention of risk or at least mitigation of the negative impact of risk factors on the company's employees requires reliable management of ergonomic factors risk, which can occur due to insufficient management of processes, quality, possible emergency situations, accidents. The above aim can be achieved by various preventive measures, just keeping in mind that the procedures of the management of ergonomic risk factors are based on assessment of ergonomic risk factors and priorities focusing on the relevant occupational safety aspects in the business company. However, prior to drafting an accident prevention plan, each company should consider the general environment of the company, conditions, and available resources.

Problem: insufficient attention of managers of the company to the management of ergonomic risk factors in occupational environment that would allow for striving for the company's aims and mitigating the negative impact of ergonomic risk factors on the company's employees.

There is research object - management of ergonomic risk factors in working environment. Research aim: having made assessment of the management of ergonomic risk factors in the working environment of a commercial company, to offer potential preventive measures for improvement of the situation.

The objectives set to achieve the aim of the research: to identify risks in occupational environment in terms of theoretical aspects and to determine the importance of the management of ergonomic risk factors in coping with the risks; to make assessment of the management of ergonomic risk factors in occupational environment of a commercial company; to offer potential preventive measures.

Research methods: logical and systematic analysis of research literature; gathering and analysis of statistical data; comparative analysis; grouping of survey data, the obtained results of the survey were processed by MS Excel programme.

To address the problem and to achieve the aim of the research, a survey was conducted in a commercial company in the West Lithuania Region on 1-5 May, 2013. The conducted survey showed that rather than improvement of the conditions for work itself; the increase of awareness of the applied preventive measures is required, communicating information on expediency of application of such measures and their benefit both to an employee and the results of the company performance. Opinions of the employees with longer service record have revealed that the company takes care of occupational environment of its employees and assigns funds (although minimum) to that purpose. But the information received from the recently employed and from the employees with little work experience indicates that the management - motivation process should be improved: attitude of persons in charge (especially specialists, managers, employers) towards the work with the recently employed and having little work experience employees has to be changed by paying closer attention to the adaptation process; the company's employees responsible for these tasks should timely recognise expectations, advantages, opportunities and limitations of the employees in various areas of relevant activity. A survey conducted in the company has showed that the ergonomic requirements in the working environment were considered by the respondents of the survey as important factors of their performance, and supposedly, the management of ergonomic risk factors would become an integral part of the company's performance and would facilitate improvement of the risk management process not only in the company itself, but also in this particular market. Therefore, to increase the employees' contribution to the company's performance, the management of impact of ergonomic risk factors should become an effective tool facilita- 
ting reduction of the number of accidents at work and cases of occupational diseases and at the same time eliminating infringements of organizational character. Such practice would allow the employees to work in appropriate and healthy occupational environment, to increase their productivity and to achieve better performance results of the company.

KEYWORDS: ergonomic risk factors, management process, preventive measures, occupational environment.

JEL CODES: M12, R11 